\title{
Contributions of Mass Spectrometry to the Identification of Low Molecular Weight Molecules Able to Reduce the Toxicity of Amyloid- $\beta$ Peptide to Cell Cultures and Transgenic Mouse Models of Alzheimer's Disease
}

\author{
Raluca Ştefănescu ${ }^{1}$, Gabriela Dumitrița Stanciu $1, * \mathbb{D}$, Andrei Luca ${ }^{1, *}$, Ioana Cezara Caba ${ }^{1,2}$, \\ Bogdan Ionel Tamba ${ }^{1}$ and Cosmin Teodor Mihai ${ }^{1}$ \\ 1 Center for Advanced Research and Development in Experimental Medicine (CEMEX), “Grigore T. Popa” \\ University of Medicine and Pharmacy, 16 Universității Street, 700115 Iaşi, Romania; \\ raluca.stefanescu@umfiasi.ro (R.S.); ioana-cezara.grigoriu@umfiasi.ro (I.C.C.); \\ bogdan.tamba@umfiasi.ro (B.I.T.); cosmin-teodor.mihai@umfiasi.ro (C.T.M.) \\ 2 Faculty of Pharmacy, "Grigore T. Popa” University of Medicine and Pharmacy, 16 Universitătii Street, \\ 700115 Iaşi, Romania \\ * Correspondence: gabriela-dumitrita.s@umfiasi.ro (G.D.S.); andrei.g.luca@umfiasi.ro (A.L.)
}

Academic Editor: Mark Brönstrup

Received: 7 March 2019; Accepted: 22 March 2019; Published: 24 March 2019

\begin{abstract}
Alzheimer's Disease affects approximately 33 million people worldwide and is characterized by progressive loss of memory at the cognitive level. The formation of toxic amyloid oligomers, extracellular amyloid plaques and amyloid angiopathy in brain by amyloid beta peptides are considered a part of the identified mechanism involved in disease pathogenesis. The optimal treatment approach leads toward finding a chemical compound able to form a noncovalent complex with the amyloid peptide thus blocking the process of amyloid aggregation. This direction gained an increasing interest lately, many studies demonstrating that mass spectrometry is a valuable method useful for the identification and characterization of such molecules able to interact with amyloid peptides. In the present review we aim to identify in the scientific literature low molecular weight chemical compounds for which there is mass spectrometric evidence of noncovalent complex formation with amyloid peptides and also there are toxicity reduction results which verify the effects of these compounds on amyloid beta toxicity towards cell cultures and transgenic mouse models developing Alzheimer's Disease.
\end{abstract}

Keywords: Alzheimer's Disease; amyloid- $\beta$ peptides; mass spectrometry; proteolytic enzymes; anti-aggregating compounds; in vitro models; cell viability; transgenic mouse models; cognitive dysfunction; spatial working memory

\section{Introduction}

The large and continually increasing number of people affected by Alzheimer's Disease (AD) led to an increasing number of scientific studies that aim to clarify the molecular mechanisms of this disease and to identify a noninvasive early diagnosis and treatment [1].

The presence in the brain of extracellular deposits and intraneuronal neurofibrillary tangles composed of aggregated amyloid-beta peptide and abnormally phosphorylated Tau protein respectively, are considered the most important histological changes observed post-mortem in the brain of Alzheimer's Disease patients. Amyloid beta peptide (A $\beta)$ is a 40 or 42 amino acid long peptide having the sequence $\mathrm{D}^{1}$ AEFRHDSGYEVHHQKLVFFAEDVGSNKGAIIGLMVGGVVIA ${ }^{42}$ and 
is cleaved by $\beta$ - and $\gamma$-secretase from one of the 3 major isoforms of the amyloid precursor protein (APP) namely $\mathrm{APP}_{695}, \mathrm{APP}_{751}$ and $\mathrm{APP}_{770}$. The former isoform is abundantly expressed in neuronal cells and in lower amounts in non-neuronal cells while the latter two isoforms are ubiquitously expressed [2]. Amyloid precursor proteins are type I transmembrane proteins containing a long extracellular domain, a short intracellular domain and a single-pass transmembrane domain. The cleavage of amyloid precursor proteins by $\beta$-secretase which occurs in the extracellular environment and by $\gamma$-secretase in the transmembrane domain yields in the extracellular medium the peptides $A \beta(1-40)$ and $A \beta(1-42)$. The quantitation of these two peptides in human plasma indicated a ratio of 10:1 in the case of healthy individuals and 7:3 in the case of people affected by the Familial Alzheimer's Disease (FAD) [3-5]. Both peptides self-aggregate in aqueous solutions forming oligomers and fibrils which are toxic to the neuronal cells. The nucleation time decreases with increasing concentrations of $A \beta(1-42)$ while the fibril elongation rate is higher for the pure $A \beta(1-40)$ aqueous solution. The identification of the molecular ions corresponding to the oligomers and the determination of the cross section by ion mobility mass spectrometry allowed the identification of the oligomerization mechanism for these two peptides: $A \beta(1-40)$ forms dimers and tetramers while $A \beta(1-42)$ forms dimers, tetramers, hexamers and dodecamers [6].

Current therapeutic strategies developed against AD include the identification of molecules able to form noncovalent complexes with the amyloid beta peptides and to increase their clearance from the organism affected by the disease (Figure 1) [7]. For understanding the mechanism underlying each noncovalent interaction and for establishing whether the ligand molecule blocks or enhances the oligomerization, mass spectrometry methods were developed. Among these methods, epitope mapping relies on the interaction between the immobilized antibodies that are resistant to proteolysis and the intact or enzymatically cleaved antigen followed by the mass spectrometric analysis of the dissociated antigen fragments upon addition of an acidic solution compatible with electrospray (ESI) or matrix assisted laser desorption and ionization (MALDI) ionization sources [8]. Additional results were obtained by analyzing the non-covalent complexes directly by nano-ESI/ion mobility mass spectrometry.

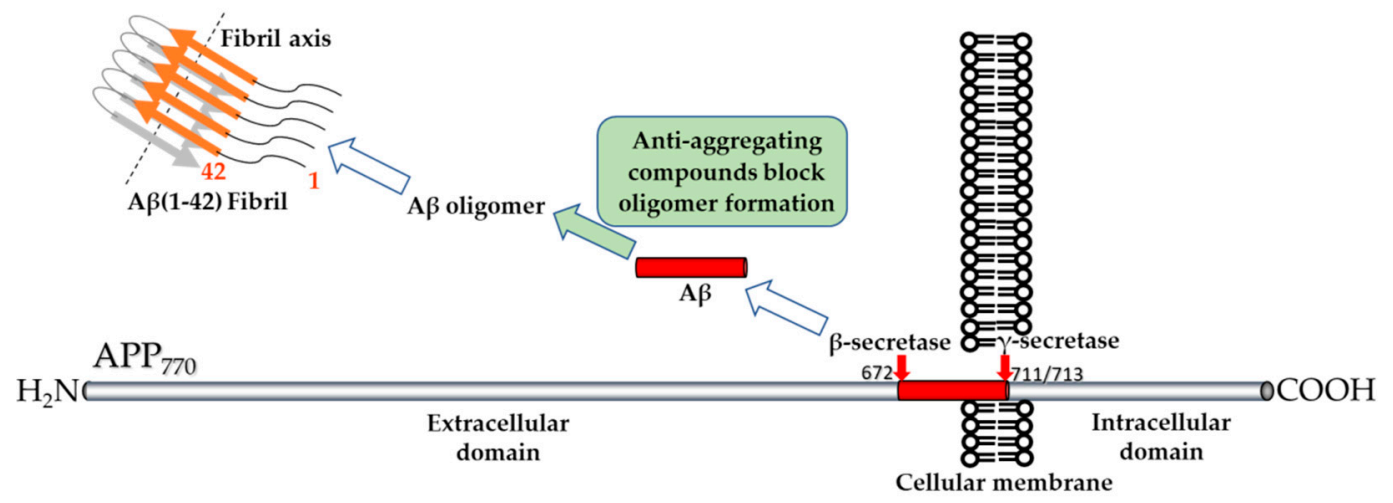

Figure 1. Schematic representation of the therapeutic strategy based on the finding of an A $\beta$ aggregation inhibitor. Cleavage of the amyloid precursor protein (APP) containing 770 amino acids, by $\beta$-secretase in the extracellular domain after methionine-671 and by $\gamma$-secretase in the transmembrane domain after valine-711 and alanine-713 produces in the extracellular medium the free peptides $A \beta(1-40)$ and $A \beta(1-42)$. Both peptides form oligomers and fibrils. Anti-aggregating compounds which inhibit the oligomerization of the amyloid peptides are searched.

For the in vitro research on $\mathrm{AD}$, several cell lines were used: as primary culture cell lines derived from rodents, cells derived from cancer cells such as neuroblastoma and pheochromocytoma cells. More recently, the researchers have focused on utilizing induced pluripotent stem cells (iPSCs) to create an AD model in vitro by transfecting cells with genes associated with early-onset Familial AD, mutant presenilin 1 (PS1), presenilin 2 (PS2) or APP. 
Human neuroblastoma (SH-SY5Y) has been used to generate an in vitro model for AD and other neurodegenerative disease by directing the SH-SY5Y cells into neuronal lineage using several differentiating factors. Fully differentiated SH-SY5Y cells have been previously demonstrated to express a variety of different markers of mature neurons including growth-associated protein (GAP-43), neuronal nuclei (NeuN), synaptophysin (SYN), synaptic vesicle protein II (SV2), neuron specific enolase (NSE) and microtubule associated protein (MAP), and to lack expression of glial markers such as glial fibrillary acidic protein (GFAP) [9].

Three important characteristics of SH-SY5Y cells should be considered when using these cells for in vitro studies [10]: (a) cultures include adherent and floating cells, both viable; (b) the parental differentiated $S K-N-S H$ cells contained two morphologically distinct phenotypes: neuroblast-like cells and epithelial-like cells from which the cells with neuroblast-like morphology contain tyrosine hydroxylase $(\mathrm{TH})$ and dopamine- $\beta$-hydroxylase that are a characteristic of catecholaminergic neurons, whereas the epithelial-like counterpart cells lack these enzymatic activities [11]; (c) SH-SY5Y cells can be differentiated to a more mature neuron-like phenotype that is characterized by neuronal markers. However, this model does not undergo all the processes which occur during the progression of AD in humans due to interaction between different cancer genes.

Immortal rat hippocampal cell lines are obtained from embryonic rat hippocampus, covering the need for cell lines derived from a known brain region origin that express phenotypes of particular subsets of cells. The cells are immortalized by retroviral mediated oncogene transduction using tsA58 and U19tsa alleles of simian virus 40 large tumour antigen. The lines morphologically differentiate to neuronal and/or glial phenotypes in culture, and express neural trophic factors known to be expressed in the hippocampus. These cell lines are thus useful for studies of development, plasticity and commitment in hippocampal lineages and for studies of receptor function and intracellular signalling pathways in mitotic versus postmitotic cells [12].

Human Induced pluripotent stem cells (iPSCs) used as models for AD have been generated from patients with APP mutations, including an E693 deletion mutation and APP gene duplication. Neurons carrying the E693 deletion case showed endoplasmic reticulum stress and oxidative stress. Also, intracellular A $\beta$ oligomers were identified. Cells from patients with the APP duplication showed increased $A \beta(1-40)$ peptide expressing increased phosphorylated-tau and increased active GSK3 beta. Models have also been generated using fibroblasts from patients with presenilin mutations, in PS1 and PS2. Cells with presenilin mutations had increased $A \beta(1-42)$ secretion consistent with pathogenic hypotheses about AD.

AD iPSCs have also been generated from patients with the V717I mutation in the APP gene. This mutation translated in dramatic increase of APP expression and A $\beta$ levels as well as elevated $\beta$-secretase cleavage of APP, resulting in increased levels of both soluble APP- $\beta$ and A $\beta$ [13].

The use of Mus musculus as translational model organism to mimic human pathology is based on the strong genetic and physiological similitudes between rodents and humans. These models allow the testing of novel therapeutic strategies as well as the study of the disease progression and fundamental pathophysiology in a manner that is impractical or unethical in people.

In the study of neurodegenerative diseases translational (knock-in, knockout or transgenic) mice are valuable models because they have corresponding, although not identical, neuronal networks and neurobiological processes with humans. Furthermore, these in vivo models are inexpensive in matters of preserving and breeding or maintaining genetic control. Currently, early-onset Familial $\mathrm{AD}$-associated mutations in amyloid precursor protein (APP), presenilin 1 (PS1) and presenilin 2 (PS2) were the most commonly used to facilitate the development of translational rodent models of AD. Nonetheless, it is necessary to consider that, none of these in vivo models of AD completely replicates the critical characteristics of the disease, represented by plaque and tangle formation, cognitive decline, synaptic loss, and neurodegeneration in a progressive manner [14].

Without a doubt, even with the above-mentioned limitations, translational AD models contribute to the enhancement of $\mathrm{AD}$ research by establishing the unique properties of each mutation and remain 
greatly useful for study of specific aspects associated with the disease appearance or progression. These models have become vital tools in improving the efficacy and safety profile of novel drugs and in surveying the temporal changes underlying the disease progression in a whole organism, studies that are typically far more limited in human subjects or tissues $[15,16]$.

In this review, we aim to identify studies that assess the anti-aggregating properties and the ability to reduce $A \beta$ toxicity of substances from different chemical classes both in vitro and in vivo. Our main focus was mass spectrometric analyses of the complexes between the substance and A $\beta$ peptides as well as the identification of the $A \beta$ segment which interacts with the substance. A comparison between the experimental conditions employed for the observation of the noncovalent complex in gas-phase and for the toxicity experiments carried out in vitro and in vivo was also performed.

\section{Low-Molecular Weight Compounds Tested for Decreasing Amyloid-Beta Peptide Oligomerization and Toxicity}

\subsection{Humanin Peptide (HN)}

Humanin is a 24 amino acid peptide having the following sequence: MAPRGFSCLLLLTSEID LPVKRRA. It was identified for the first time by Hashimoto and coworkers in the occipital lobe of the brain of an AD patient. The neuroprotective effect of humanin is abrogated when the following amino acid replacements are introduced in the sequence: P3A, S7A, C8A, L9A, L12A, T13A, S14A, P19A. The replacement of serine 14 to glycine increases neuroprotection more than 1000-fold [17].

Maftei and her collaborators established using mass spectrometry coupled to affinity chromatography methods that $\mathrm{A} \beta(1-40)$ and $\mathrm{HN}$ form a non-covalent complex and identified the sequence from both $\mathrm{A} \beta(1-40)$ and $\mathrm{HN}$ involved in the interaction [18]. They reported the semi-automated synthesis of the following peptides: humanin (HN), humanin (3-19), humanin preceded by an amino-terminal pentaglycine spacer (G5HN), humanin that possesses an amino-terminal pentaglycine spacer biotinylated at the amino-terminal end (BG5HN), humanin preceded by biotin and an amino-terminal pentaglycine spacer carrying one of the following mutations S14G, C8A, C8C (Acm) or C8S. Crude and purified peptides were analyzed using a MALDI-TOF Bruker Biflex II linear mass spectrometer in order to establish whether the correct peptide sequence was obtained. The formation of a non-covalent complex between HN and $A \beta(1-40)$ was verified by immobilizing $A \beta(1-40)$ on NHS-activated Sepharose and incubating the affinity chromatography medium obtained with an equimolar mixture of $\mathrm{HN}$ and neurotensin. The supernatant fraction collected after incubation and the elution fraction collected after washing the affinity medium and dissociating the complex with $0.1 \%$ trifluoroacetic acid were lyophilized, desalted using Zip-Tip and analyzed by MALDI-TOF. The presence of HN only in the elution fraction indicated that the $\mathrm{HN}$ bound specifically to $\mathrm{A} \beta(1-40)$ while neurotensin was present only in the supernatant, indicating that this peptide did not form a complex with $A \beta(1-40)$. The authors analyzed using a nano-ESI-FTICR mass spectrometer, a solution containing C8A mutant peptide at $25 \mu \mathrm{M}$, $\mathrm{A} \beta(1-40)$ at $50 \mu \mathrm{M}$ and $0.5 \mathrm{mM}$ ammonium acetate $(\mathrm{pH}$ 6). In the mass spectrum, a molecular ion carrying five positive charges whose $m / z$ value corresponds to the complex between C8A mutant peptide and $A \beta(1-40)$ was observed. For the identification of the binding sequence of both humanin and $A \beta(1-40)$ affinity columns were prepared, having $A \beta(1-40)$ or humanin immobilized on NHS-activated Sepharose which allowed each affinity media to interact with the binding partner digested by trypsin, chymotrypsin or protease Glu-C prior to the addition in the affinity column or digested after the formation of the complex. The results indicated that the sequences $H N(5-15)$ and $A \beta(17-28)$ are involved in the interaction between humanin and $A \beta(1-40)$ (Figure 2).

The neuroprotective effect of HN-S14G on the toxicity induced by A $\beta(25-35)$ over PC12 (rat phaeochromocytoma) cells and its potential mechanisms were investigated. Incubation of PC12 cells with $\mathrm{A} \beta(25-35)(25 \mu \mathrm{M})$ caused cellular viability loss, decrease of mitochondrial membrane potential and increase in cytochrome $C$ releases from mitochondria leading to cell apoptosis. All these toxic effects were inhibited by pretreatment with HN-S14G (100 nM) 6 h before exposure to A $\beta(25-35)$ : 
cell toxicity and apoptosis were reduced; mitochondrial membrane potential was stabilized and the release of cytochrome $\mathrm{C}$ from mitochondria was blocked. HN-S14G also ameliorated the $\mathrm{A} \beta(25-35)$-induced $\mathrm{Bcl}-2 / \mathrm{Bax}$ ratio reduction (downregulation of $\mathrm{Bcl}-2$ and upregulation of $\mathrm{Bax}$ ) and decreased caspase- 3 activity in PC12 cells. These findings indicate that mitochondria are involved in the protective effect of HN-S14G against $\mathrm{A} \beta(25-35)$ [19].

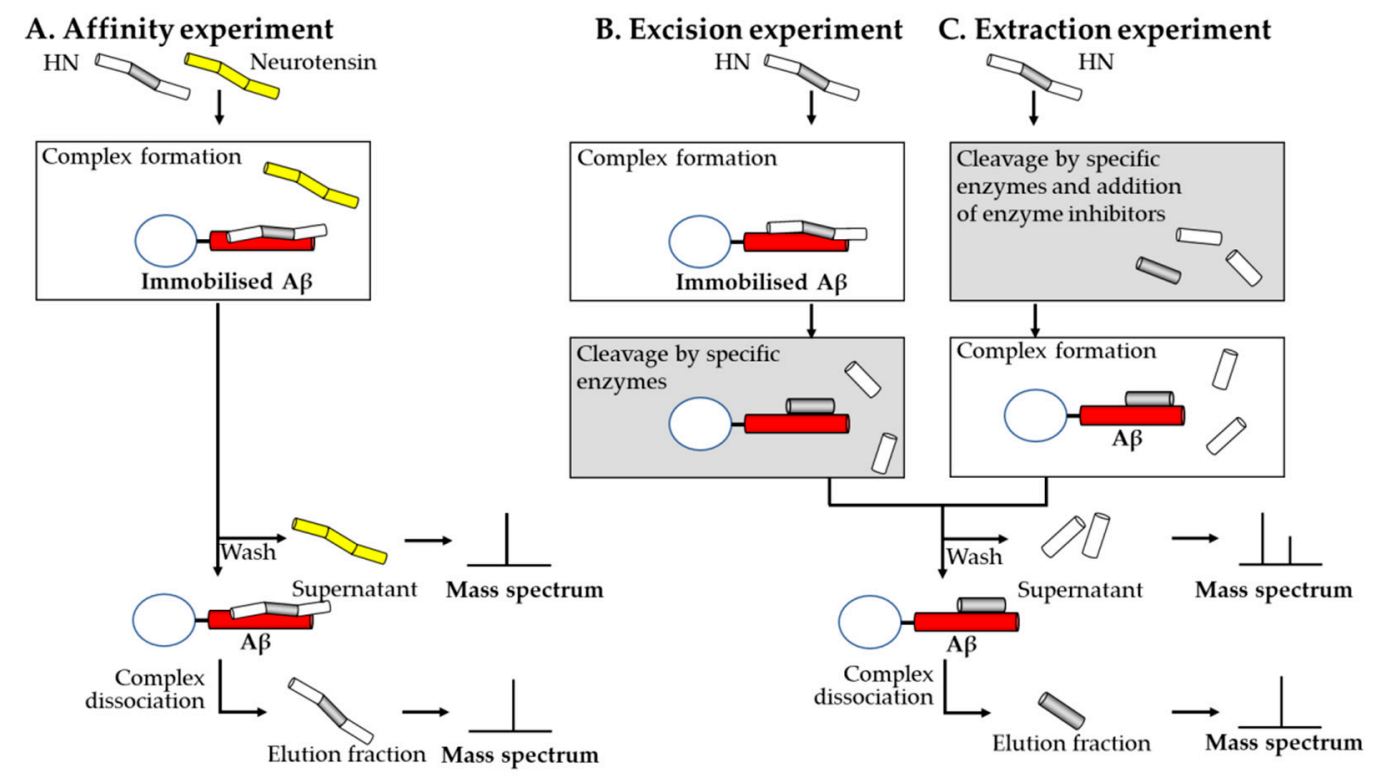

Figure 2. Schematic representation of the affinity mass spectrometric experiments carried out for the identification of the binding sequences of two peptides forming a complex using one immobilized binding partner. (A) Scheme of an affinity experiment using immobilized $\mathrm{A} \beta$ peptide. A mixture of humanin and neurotensin is incubated with the affinity medium. The mass spectrum of the supernatant should contain non-binding peptides and the mass spectrum of the elution fraction should contain the peptides presenting affinity towards amyloid-beta peptide. (B) In the excision experiment, intact humanin is incubated with immobilized $A \beta$ followed by proteolytic cleavage of the peptide fragments that are not protected against proteolysis through the interaction. Mass spectrum of the supernatant reveals the regions from humanin which do not interact with $\mathrm{A} \beta$ while the mass spectrum of the elution fraction shows the region which is involved in the interaction. (C) In the extraction experiment humanin is first proteolitically cleaved, then protease inhibitors are added and the mixture is incubated with immobilized $A \beta$. The mass spectra of the supernatant and elution fractions obtained from both the excision and extraction experiments indicate the binding region of humanin.

Both in vivo and in vitro studies sustained the protective effects of $\mathrm{HN}$ which seems to act as a signal peptide constraining neurotoxicity from several AD related insults. In vitro findings highlighted that $\mathrm{HN}$ might antagonize neurotoxicity induced by a wide range of FAD related proteins including APP, PS1, PS2, and A $\beta$ peptides, such as A $\beta(1-42)$ and A $\beta(25-35)$ [20]. Similarly, in vivo evidence, risen from intracerebroventricular (icv) delivery of doses greater than 50 pmol of HN-S14G followed by Y-maze measurements, plea for proprieties against deterioration of short-term and spatial working memory caused by $\mathrm{A} \beta(25-35)(10 \mathrm{nmol} / 5 \mu \mathrm{L} / \mathrm{site}$, icv $)$ which was injected 21 days before testing [21].

Additionally, chronic administration of HN-S14G treatment (3-month, $0.1 \mu \mathrm{g} / 0.5 \mathrm{~mL}$ of HN-S14G diluted in normal saline solution, through ip delivery) significantly ameliorated spatial learning and memory deficits, reduced $\mathrm{A} \beta$ plaque accumulation and insoluble $\mathrm{A} \beta$ concentrations, decreasing neuroinflammatory responses in middle-age APPswe /PS1dE9 mice [22]. Niikura et al. [23] reported similar outcomes in APPswe, tauP310L, and PS1M146V triple transgenic mice $(3 \times \mathrm{Tg}$-AD) following chronic intranasal instillation with $10 \mathrm{nmol}$ of HN-S14G. With both total amount and phosphorylation status of tau unaffected, it appears that cytoprotective effect of $\mathrm{HN}$ is independent of tau pathology [23,24]. 


\subsection{Tramiprosate}

Martineau and his collaborators investigated the noncovalent interaction between tramiprosate and the following peptides: (i) $\mathrm{A} \beta(1-40)$, (ii) $\mathrm{A} \beta(1-42)$, (iii) $\mathrm{A} \beta(1-28)$ (iv) $\mathrm{A} \beta(1-28)$ all (-) carrying only negatively charged amino acids which contained the mutations D1G, E3S, R5G, D7A, K16E, D23S, $\mathrm{K} 28 \mathrm{~S}$, and (v) A $\beta(1-28)$ all (+) carrying only positively charged amino acids having the mutations $\mathrm{D} 1 \mathrm{G}$, E3S, D7A, E11S, E22S, D23A.

$\mathrm{A} \beta$ peptide in $0.1 \%$ trifluoroacetic acid and deionized water together with tramiprosate in deionized water were mixed in order to achieve a final concentration of $30 \mu \mathrm{M}$ and $150 \mu \mathrm{M}$. The $\mathrm{pH}$ of the resulting solution was adjusted to 7.4 using $0.1 \% \mathrm{NaOH}$. Mass spectrometric analyses of the complexes were carried out in positive mode using a ZQ 4000 mass spectrometer produced by Waters. Based on the height of the peaks from all ionic species of the peptide and complex the researchers calculated the binding affinity of tramiprosate to $A \beta$ peptides and obtained the following results: $28 \pm 3 \%$ for $A \beta(1-42), 33 \pm 1 \%$ for $A \beta(1-40), 33 \pm 3 \%$ for $A \beta(1-28), 16 \pm 2 \%$ for $A \beta(1-28)$ all $(-)$ and 0 for $\mathrm{A} \beta(1-28)$ all $(+)[25]$.

Gervais and her collaborators demonstrated that tramiprosate forms non-covalent complexes with $A \beta(1-40), A \beta(1-42)$ and $A \beta(1-28)$ by infusing directly an aqueous solution containing $20 \mu \mathrm{M}$ $\mathrm{A} \beta$ peptide alone or with $200 \mu \mathrm{M}$ tramiprosate adjusted with $0.1 \% \mathrm{NaOH}$ to the $\mathrm{pH} 7.4 \pm 0.2$ into the Micromass Q-TOF Micro mass spectrometer. Similarly, the researchers showed that taurine and $\mathrm{N}$-acetylated homotaurine bind to $\mathrm{A} \beta(1-40)[26]$.

Kocis and his collaborators employed the mass spectrometer Synapt G2-S Q-TOF and performed ion mobility separation coupled to mass spectrometry for the characterization of $A \beta(1-42)$ monomers and oligomers in the absence or presence of tramiprosate. Stock solutions of $5 \mathrm{mg} / \mathrm{mL} \mathrm{A} \beta(1-42)$ and $1 \mathrm{mg} / \mathrm{mL}$ tramiprosate were prepared by separately dissolving $1 \mathrm{mg}$ of these two substances in LC/MS grade water. Final solutions were prepared, containing $22 \mathrm{pmol} / \mu \mathrm{L} \mathrm{A} \beta(1-42)$ in water alone or mixed with 10-, 100- or 1000-fold molar excess of tramiprosate. The samples were infused in the mass spectrometer after 0,4 or $24 \mathrm{~h}$ incubation at room temperature. The analysis of the mass spectra recorded for the samples of $A \beta(1-42)$ incubated for $24 \mathrm{~h}$ in the absence or in the presence of tramiprosate led to the conclusion that in the absence of tramiprosate, $A \beta(1-42)$ solution contains monomers, dimers, trimers, tetramers, pentamers, hexamers and decamers. By comparison in the presence of a 1000-fold molar excess of tramiprosate, only monomers of $A \beta(1-42)$ were observed. Additionally, the authors observed that the monomer of $A \beta(1-42)$ was able to form noncovalent complexes with up to 6 molecules of tramiprosate and together with the fact that the drift times became shorter with the increasing number of bound tramiprosate molecules they concluded that the conformations of the $A \beta(1-42)$ were fewer [27].

The treatment of primary rat neuronal cultures with a dose of $5 \mu \mathrm{M} \mathrm{A} \beta(1-42)$ has induced, $58.1 \pm 3.4 \%$ dead neuronal cells after $72 \mathrm{~h}$, while the treatment with a mixture of $100 \mu \mathrm{M}$ tramiprosate and $5 \mu \mathrm{M} \mathrm{A} \beta(1-42)$ showed through a decrease in the number of dead neuronal cells $(35.6 \pm 5.2 \%)$ the protective activity of tramiprosate [26].

Similarly, daily subcutaneous therapy with tramiprosate in AD TgCRND8 transgenic mice (30 or $100 \mathrm{mg} / \mathrm{kg}$ over 8-9 weeks) revealed a statistically significant decrease of neocortical plaques load by $30 \%$. Combined with the data according to which a reduction between $20-30 \%$ in brain levels of soluble and insoluble $A \beta(1-40)$ and $A \beta(1-42)$ occurred and that a dose-dependent decrease of around $60 \%$ in $A \beta$ plasma levels took place, the hypothesis that tramiprosate influences the main deposit of $A \beta$ by changing its brain efflux or catabolism emerged $[25,26]$.

\subsection{Melatonin}

Bazoti and collaborators, using two mass spectrometers equipped with electrospray sources, reported in 2005 the formation of a noncovalent complex between $A \beta(1-40)$ and melatonin, the pineal hormone. The researchers used an equimolar mixture of both substances at different concentrations and found that the concentration of $100 \mu \mathrm{M}$ produced the most abundant signals of the complex 
formed between melatonin and $A \beta(1-40)$. The results indicated that only one molecule of melatonin bound to one molecule of $A \beta(1-40)$. In this study specific proteolytic enzymes (trypsin, chymotrypsin, Glu-C) were used in order to identify the binding amino acid sequence. When the enzymatic digestion was performed prior to the formation of the non-covalent complex the mixture analyzed at the mass spectrometer revealed the presence of various peptide fragments bound separately to one molecule of melatonin. When the non-covalent complexes were digested with proteolytic enzymes the mass spectra of the mixtures obtained indicated also that multiple proteolytic peptides bound separately to one molecule of melatonin. Incomplete digestion with trypsin prior or after the formation of the non-covalent complex led to the observation of two peptide fragments and one molecule of melatonin [28].

Investigations performed using murine N2a neuroblastoma demonstrated that melatonin $(10 \mu \mathrm{M})$ had cytoprotective effect and prevented cell death when it was co-incubated with $A \beta(25-35)$ $(50 \mu \mathrm{M})$ [29].

An earlier report of experiments carried out in vivo on chronic melatonin treatment $(0.5 \mathrm{mg} / \mathrm{mL})$ started at 4 months of life and continued up to different time points $(8,9.5,11$ and 15.5 months) on $\operatorname{Tg} 2576$ mice was correlated with limited inhibition of the expected time-dependent elevation of $A \beta$, reduction of protein nitration and an improvement in survival [30]. Additionally, Quinn et al. [31] displayed that melatonin did not disturb the expression of APP holoprotein in the same Tg2576 mice model. Recently, Gong et al. [32] have revealed that melatonin treatment significantly attenuates cognitive deficits in $A \beta(1-42)$-induced mouse model. Doses of 10,5 or $2.5 \mathrm{mg} / \mathrm{kg}$ melatonin were administered intraperitoneally for 14 days after $48 \mathrm{~h}$ from the icv injection of 410 pmol A $\beta(1-42)$, dissolved in $5 \mu \mathrm{L}$ PBS and inoculated in $2 \mathrm{~min}$. Moreover, melatonin has reduced mitochondrial impairments and alleviated the expression of the phosphorylated-tau and several major proteins involved in apoptosis. These important results testify that melatonin has the capacity to control APP metabolism and inhibit $A \beta$ pathology, but if it is administered after the development of $A \beta$ deposits, it fails to have anti-amyloid or antioxidant properties. Furthermore, the in vivo results encouraged the use of melatonin and its analogs in the prevention of $\mathrm{AD}$ in high-risk populations [33].

\subsection{Oleuropein}

The complex formed by $A \beta(1-40)$ and oleuropein, a polyphenol found in the fruits and leaves of Olea europaea L. was investigated. The peptide $A \beta(1-40)$ was incubated with oleuropein at a 1:1 molar ratio by mixing identical volumes of $100 \mu \mathrm{M} \mathrm{A} \beta(1-40)$ freshly prepared in deionized water and of oleuropein solubilized in $1 \mathrm{mM}$ ammonium acetate containing $0.5 \%$ acetic acid. The molecules were allowed to interact for different time intervals during 25 days prior to the extraction and direct infusion of a small sample aliquot into the SCIEX API III triple quadrupole mass spectrometer. The researchers identified in the mass spectra the signals corresponding to the molecular ions carrying 4 to 6 positive charges of the complex between one molecule of peptide and one molecule of oleuropein. They also determined experimentally the optimal $\mathrm{pH}$ value, electrospray source parameters and percentage of organic modifier establishing that the stoichiometry of the complex was neither influenced during the optimization of the solution concentrations of analytes, solvents or electrospray source parameters nor by addition of a ten-fold molar excess of oleuropein in comparison with amyloid beta (1-40) peptide [34].

In a second study by the same team, proteolytic digestion using specific enzymes (trypsin and Glu-C) was performed. The resulting mixtures of peptides were analyzed using a Bruker Daltonics BioAPEX-94e superconducting 9.4 T FT-ICR mass spectrometer equipped with an electrospray ionization source and multiple proteolytic fragments bound separately to one molecule of oleuropein were observed in the mass spectra (Figure 3) [35].

To confirm the protective effect of oleuropein against $A \beta(1-42)$-induced toxicity, the viability of SH-SY5Y cells pre-incubated with different doses of oleuropein $(10,50,250$ and $1000 \mu \mathrm{M})$ for $24 \mathrm{~h}$ prior to the addition of a $25 \mu \mathrm{M}$ solution containing fibrils of $\mathrm{A} \beta(1-42)$ was evaluated. The results indicated 
that in the absence of oleuropein, $25 \mu \mathrm{M} \mathrm{A} \beta(1-42)$, determines a cell viability of only $40 \%$. After the pre-incubation with increasing concentrations of oleuropein the number of viable cells increased at $48 \%$ at $10 \mu \mathrm{M}$ oleuropein and $68 \%$ at $1000 \mu \mathrm{M}$ oleuropein [36].
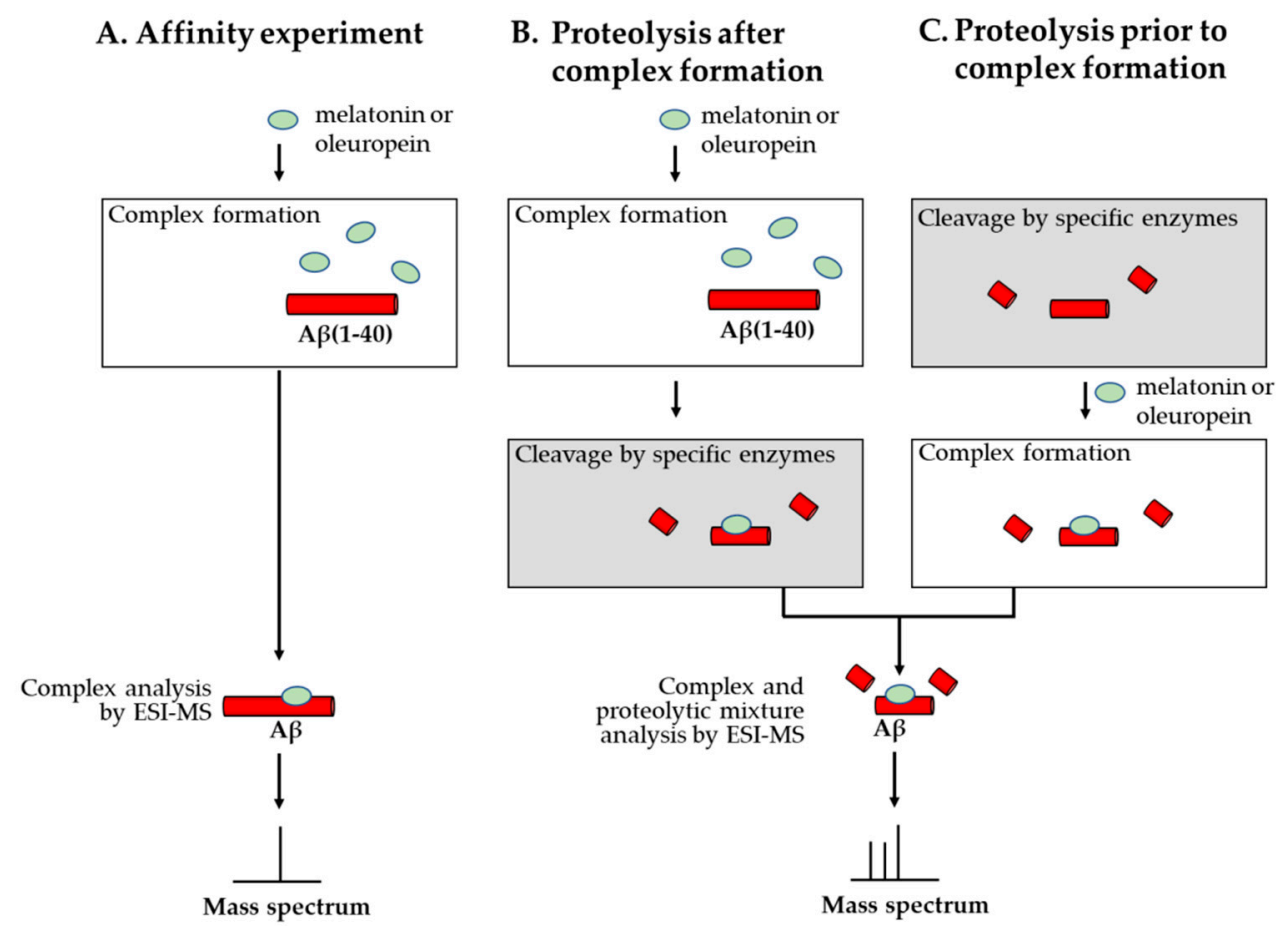

Figure 3. Schematic representation of the affinity mass spectrometric experiments carried out for the identification of the binding region from $A \beta$ interacting with the test substances melatonin and oleuropein. (A) In the affinity experiment, incubation of $A \beta(1-40)$ with melatonin or oleuropein in a suitable buffer for ESI-MS analysis indicates whether a noncovalent complex is formed. (B) Complex formation followed by cleavage with specific proteolytic enzymes and analysis of the complex together with the proteolytic mixture by ESI-MS allows the identification of the binding region from $A \beta$. (C) Proteolysis prior to complex formation and analysis of the mixture by ESI-MS allows the identification of the peptides that are incomplete and do not maintain affinity to the tested substance.

Current data dealing with eight weeks of consumption of oleuropein aglycone in dietary therapy (50 mg/ $\mathrm{kg}$ diet daily intake) for young-middle aged TgCRND8 and wild type mice offer convincing evidence that it improves the behavior of animals in step-down inhibitory avoidance and object recognition tests with regard to typically fed littermates. Enhanced behavior is sustained by a substantial reduction in $A \beta(1-40)$ and $A \beta(1-42)$ levels, in area and consistency of amyloid plaques and by the occurrence of soft deposits in the older mice [37].

The level of oleuropein aglycone to interplay with amyloid- $\beta$ proteotoxicity in vivo by using the transgenic mice (TgCRND8) was evaluated by Pantano et al. [38]. Adding to the diet $12.5 \mathrm{mg} / \mathrm{kg}$ or $0.5 \mathrm{mg} / \mathrm{kg}$ of oleuropein aglycone an improvement in cognitive outcomes in two memory tests was recorded. Moreover, a reduction in the number and size of $A \beta(1-42)$ plaques present in the brain cortex of the treated animals was found. In light of the above findings we can conclude that oleuropein aglycone compensates for $A \beta$ aggregation and modulates the neurotoxicity attributed to the last of them and disturbs diverse pathways such as the processing of amyloid precursor proteins, the amyloid- $\beta$ and tau protein aggregates, autophagy damage and neuroinflammation [39].

\subsection{Trehalose}

Wei Qi and collaborators reported in 2009 adducts formed by trehalose and $A \beta(1-40)$ using concentrations of $100 \mu \mathrm{M}$ peptide and disaccharide concentrations of $0.1 \mathrm{mM}, 10 \mathrm{mM}, 50 \mathrm{mM}, 100 \mathrm{mM}$ 
and $250 \mathrm{mM}$. At the concentration of $250 \mathrm{mM}$ trehalose the number of disaccharide molecules which form adducts with one molecule of $A \beta(1-40)$ is 9 [40].

Liu and the collaborators investigated the effects of different concentrations of trehalose on the toxicity exerted by $A \beta(1-40)$ and $A \beta(1-42)$ towards human neuroblastoma cells (SH-SY5Y). Fibrils of $A \beta(1-40)$ and $A \beta(1-42)$ were obtained by incubating these peptides over a four days and $12 \mathrm{~h}$ interval, respectively. Medium solutions containing fibrils of $A \beta(1-40)$ and $A \beta(1-42)$ at final concentrations of $800 \mathrm{nM}$ and $400 \mathrm{nM}$ respectively were prepared and added to the cells. At the addition of $\mathrm{A} \beta(1-40)$ the resulting cellular populations contained $64 \%$ viable cells in comparison with control cells and in the case of $A \beta(1-42)$ only $62 \%$ viable cells. The addition of $0.1 \mathrm{mM}, 1 \mathrm{mM}, 10 \mathrm{mM}$ or $50 \mathrm{mM}$ trehalose at the beginning of the fibril formation step in the case of $A \beta(1-40)$, the cellular viability increased in a dose-dependent manner up to $100 \%$ at the highest trehalose concentration, however, showed no effect towards the toxicity exerted by $A \beta(1-42)$ when added to the $A \beta(1-42)$ solution at the beginning of fibril formation step. [41]

Trehalose treatment ( $2 \%$ solution) for AD Tg2576 transgenic mice (a daily oral dose of $0.1 \mathrm{~mL} / 10 \mathrm{~g} / \mathrm{b} . \mathrm{w}$. daily for 31 days) remarkably increased performance in a behavioral test, corresponding with improved learning and memory. Improvement of cognitive outcomes was not correlated with a substantial modulation of $A \beta$ peptide precursors [42]. Compelling findings have also been reported by Du et al., [43] in the treatment of AD APP/PS1 transgenic mice with trehalose ( $2 \mathrm{~g} / \mathrm{L}$ of trehalose delivered into the right lateral ventricles). Cognitive impairment and learning deficits were ameliorated, while $\mathrm{A} \beta$ aggregates at the hippocampus and cerebral cortex were diminished. These reports support the theory by which trehalose can access a series of neural protective mechanisms to enhance the cognitive functions in $\mathrm{AD}$ that are independent of most trehalose-mediated pathways, including reduction of $A \beta$ and autophagy activation. Moreover, trehalose appears to have a protective role in denaturing and conformational protein changes in some neurological diseases such as Alzheimer's and Parkinson's disease [44].

\section{6. $\beta$-cyclodextrin}

Camilleri and his collaborators investigated in 1994 the interaction between $A \beta(1-40)$ and $\beta$-cyclodextrin using a mass spectrometer equipped with an electrospray source and a single quadrupole mass analyzer. Although $A \beta(1-40)$ peptide and $\beta$-cyclodextrin were solubilized in a solvent containing water, methanol and acetic acid which are denaturing experimental conditions, a strong signal corresponding to the quadruply charged ion of the complex between one molecule of $\beta$-cyclodextrin and one molecule of $A \beta(1-40)$ was observed in the mass spectrum [45].

$\beta$-Cyclodextrin has proven to reduce the neurotoxicity of $A \beta(1-40)$ towards PC12 cells (rat phaeochromocytoma) in a dose dependent manner. At the maximum dose $(23 \mu \mathrm{M})$ of $\mathrm{A} \beta(1-40)$, the cytotoxic effect was of approximately 55\%, while the incubation of the PC12 cells with both $\mathrm{A} \beta(1-40)$ and $\beta$-cyclodextrin $(75 \mu \mathrm{M})$ led to a reduction in cell viability of only $30 \%$ at $24 \mathrm{~h}$ [45].

Investigation of the potential protection role of 2-hydroxypropyl- $\beta$-cyclodextrin (HP- $\beta$-CD), a $\beta$-cyclodextrin derivative possessing higher solubility in aqueous solutions, was based on viability assessment into SH-SY5Y cells (human neuroblastoma). In the control group, in which pure HP- $\beta$-CD $(125 \mu \mathrm{m})$ was added, no signs of cytotoxicity were registered and cell viability at $48 \mathrm{~h}$ in cell culture was of $98.8 \%$. The pure $\mathrm{A} \beta$ was highly toxic to cells, whose viability was dramatically decreased to $48 \%$ at $48 \mathrm{~h}$, causing morphological changes (cell body shrinkage and aggregation). When incubating HP- $\beta$-CD with $A \beta(1-42), H P-\beta-C D$ was able to protect cells from the $A \beta$-induced cell toxicity. The viability at different ratios (1:1, 1:2, and 1:5) of added A $\beta-H P-\beta-C D$ mixture varied between $74 \%, 93 \%$ and $82 \%$ at $24 \mathrm{~h}$ greater than that of $A \beta$ alone $(60 \%)$. Further increase of incubation time to $48 \mathrm{~h}$ led to continuous, but overall minor decrease in cell viability to $61 \%, 91 \%$, and $75 \%$ at $1: 1$, $1: 2$, and 1:5 ratios, respectively, suggesting that HP- $\beta-C D$ can retain its long-term neuroprotection against A $\beta$-induced toxicity in SH-SY5Y cells, especially at 1:2 molar ratio which demonstrated the most potent protective effect [46]. 
The therapeutic properties of HP- $\beta$-CD were evaluated on an AD Tg19959 mice model by Yao et al., [47]. Subcutaneous administration of $4.000 \mathrm{mg} / \mathrm{kg}$ HP- $\beta-C D$ compound twice a week over a 4 -month period beginning at 7 days of age resulted in an improvement over memory impairments and spatial learning, reduction of the $A \beta$ aggregates production as well as tau cerebral cortex and hippocampus immunopositive dystrophic neuritis. Moreover, as a consequence of reducing the cleavage of APP protein and upregulation for the expression of some genes involved in the transport of cholesterol, a decrease in amyloid aggregates in the brains of mice was observed. HP- $\beta-C D$ has a direct action on intensifying cholesterol transport and $A \beta$ clearance through $A B C A 1$ modulation. In an AD model with Npc1-deficient mice, HP- $\beta-C D$ therapy increased the lifespan and ameliorated behavioral deficits and pathological abnormalities accompanying the experimental model [48].

HP- $\beta$-CD short-term therapy (two weeks) on autophagy in vivo, on wild-type and adult/old TgCRND8 mice in varying concentrations over the three routes of administration (ip delivery: $4000 \mathrm{mg} / \mathrm{kg} /$ day $20 \% \mathrm{HP}-\beta-C D$ solution; icv: $40 \mathrm{mg} / \mathrm{kg} /$ day, $2 \mu \mathrm{L}$ of $40 \%$ solution of HP- $\beta-\mathrm{CD}$, or intrahippocampal injection: single dose of 0.06 or $0.12 \mathrm{mg}, 0.3 \mu \mathrm{L}$ of 20 or $40 \%$ HP- $\beta$-CD solution) has been evaluated. The outcomes revealed that icv delivery of HP- $\beta-C D$ significantly reduced the dimensions of enlarged autolysosomes and dropped the GM2 ganglioside and A $\beta$-immunoreactivity without changing APP proteins processing, extracellular $A \beta$ or $\beta$-amyloid burden. The main mechanisms by which HP- $\beta-C D$ acts on autophagy are represented by stimulation of lysosomal proteolytic activity by growing cathepsin $\mathrm{D}$ action and by preventing autophagosome-lysosome synthesis [49].

\subsection{GRKKRRQRRR-GGGG-DVEFRH Peptide}

Cimini and her collaborators employed a MALDI-TOF/TOF 4800 mass spectrometer produced by Applied Biosystem for the MALDI-imaging mass spectrometric investigation of $15 \mu \mathrm{m}$ thick slices of brain obtained from mice sacrificed after 6 and $24 \mathrm{~h}$ from the intraperitoneal administration of the peptide designated A $\beta(1-6) A 2 \operatorname{VTAT}(\mathrm{D})$. The amino acid sequence of this peptide is GRKKRRQRRR-GGGG-DVEFRH and the amino acids used for its synthesis were all D-FMOC amino acids. The authors observed abundant peptide signals in the brain slices obtained $6 \mathrm{~h}$ after treatment as compared with less abundant peptide signals in the brain slices collected $24 \mathrm{~h}$ after administration and concluded that the peptide crossed the blood brain barrier [50].

Treatment of SH-SY5Y cells with A $\beta(1-6)(D)$ or $A \beta(1-6) A 2 V(D)$ showed that neither is toxic for living cells even at high concentrations $(20 \mu \mathrm{M})$ and that both peptides can reduce the toxicity induced by $\mathrm{A} \beta(1-42)$. However, $\mathrm{A} \beta(1-6) \mathrm{A} 2 \mathrm{~V}(\mathrm{D})$ showed a stronger effect in counteracting the reduction of cell viability caused by $A \beta(1-42)(35 \%)$, suggesting that the A-to-V substitution actually amplifies the protective effects of the six-mer peptide.

$\mathrm{A} \beta(1-6) \mathrm{A} 2 \mathrm{VTAT}(\mathrm{D})$ is not toxic when added to culture medium at concentrations ranging between 1 and $5 \mu \mathrm{M}$, while it reduces cell viability at higher concentrations. A $\beta(1-6) A 2 \mathrm{VTAT}(\mathrm{D})$ showed a dose-dependent effect in reducing $A \beta(1-42)$ toxicity [51]. Investigation of $A \beta(1-6) A 2 V T A T(D)$ cytotoxic impact on primary hippocampal neurons did not induce neuronal death at any of the concentrations tested $(2-20 \mu \mathrm{M})$ after $24 \mathrm{~h}$ incubation, as assessed through MTT and LDH assays. Also, $\mathrm{A} \beta(1-6) \mathrm{A} 2 \mathrm{VTAT}(\mathrm{D})$ peptide reverted soluble $\mathrm{A} \beta(1-42)$ toxicity in vitro [50].

An in vivo report performed on AD APPswe/PS1dE9 mice revealed that short-term therapy (2.5 months) with $10 \mathrm{mg} / \mathrm{kg}$ A $\beta(1-6)$ A2VTAT (D) ip administration weekly, results in a decrease of A $\beta$ production and accumulation, with inhibition of amyloid deposition in all cerebral areas. Moreover, there was an augmentation in the soluble fraction of $A \beta(1-42)$ associated with a reduction of the insoluble compartment, indicating that the therapy may lead to a transfer of $A \beta(1-42)$ from the insoluble to soluble fraction of cerebral tissue, which may consider a disruption of amyloid deposits. Instead, a prolonged therapy ( 5 months) leads to an unexpected augmentation of amyloid burden even if it avoids cognitive impairment [51]. The unwanted results of the long-term treatment with 


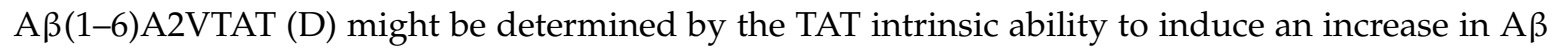
production, phosphorylation of tau and then neuronal death during AD development [52].

Evaluating the synaptotoxic effect of some oligomers formed by the aggregation of various $A \beta$ peptides, revealed that a single ip injection $(20 \mathrm{mg} / \mathrm{kg})$ of A $\beta(1-6)$ A2VTAT (D) administered to the TgCRND8 mice ameliorated the postsynaptic alterations of GluN2A, GluA1, GluA2 values and the scaffold PSD-95 level was considerably augmented. These findings suggest that A $\beta(1-6) A 2 V T A T(D)$ peptide in some measure contrasts AD synaptopathy [50].

\subsection{Ac-VVIA and VVIA-NH $\mathrm{N}_{2}$ Peptides}

Two four amino acid long peptides corresponding to the carboxy-terminal end of the peptide $A \beta(1-42)$ were synthesized for testing the binding to the $A \beta(1-42)$ peptide and the disaggregating effects on preformed oligomers; the first one acetylated at the amino-terminal end Ac-VVIA and the second one possessing an amidated carboxy-terminal end VVIA- $\mathrm{NH}_{2}$ [53]. Using an ion mobility spectrometer-mass spectrometer the researchers observed that a $10 \mu \mathrm{M}$ solution of $\mathrm{A} \beta(1-42)$ prepared in a $10 \mathrm{mM}$ ammonium acetate buffer solution having the $\mathrm{pH} 7.4$ yielded dimers, tetramers, hexamers and dodecamers. The addition of the peptide Ac-VVIA during the formation of the oligomers caused the disappearance of the $A \beta(1-42)$ dodecamers. The incubation of the peptide $A \beta(1-42)$ with the peptide VVIA- $\mathrm{NH}_{2}$ resulted in a diminished concentration of the hexamer and the absence of the dodecamer. Moreover the mass spectra indicated the presence of complexes between each of the two tetrapeptides and the $\mathrm{A} \beta(1-42)$ peptide (Figure 4).

A.

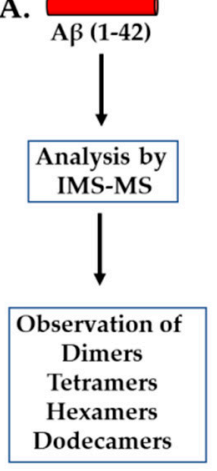

B.

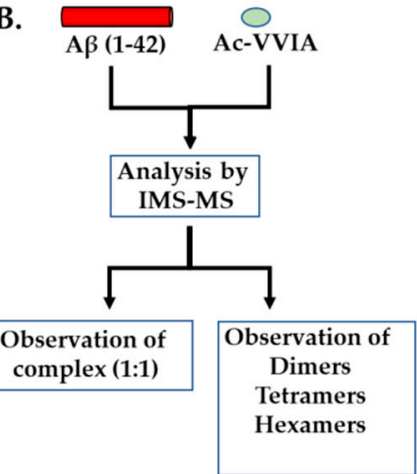

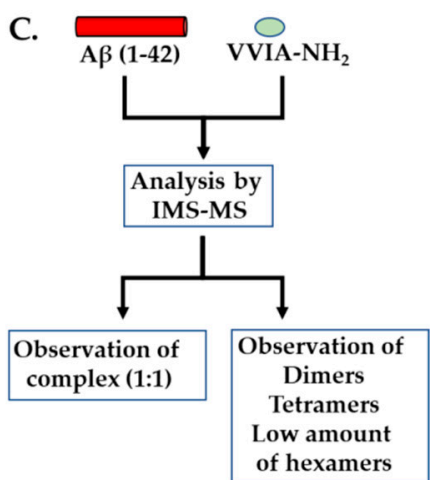

Figure 4. Schematic representation of the ion mobility spectrometry-mass spectrometry experiments performed for the investigation of $A \beta(1-42)$ oligomerization in the absence (A) or presence of the tetrapeptides Ac-VVIA (B) and VVIA-NH2 (C).

Evaluation of cytotoxicity of VVIA- $\mathrm{NH}_{2}$ in PC-12 cells concluded that VVIA- $\mathrm{NH}_{2}$ did not induce toxic effects, by contrary causing a significant increase of $10-35 \%$ in cell viability compared to control cells. Investigation of VVIA- $\mathrm{NH}_{2}$ capacity to inhibit A $\beta 42$-induced neurotoxicity in single-dose experiments, the PC-12 cells were incubated with $\mathrm{A} \beta 42$ for $24 \mathrm{~h}$ in the absence or presence of 10 -fold excess of VVIA- $\mathrm{NH}_{2}$, proving its capacity to significantly attenuate the $\mathrm{A} \beta 42$-induced toxicity. The Ac-VVIA showed no inhibitory activity [54].

\subsection{RYYAAFFARR Peptide}

Liu and his collaborators investigated the binding to $A \beta(1-40)$ of the peptide Ac-RRYYAAFFARR- $\mathrm{NH}_{2}$ using surface plasmon resonance assay and carried out MALDI-TOF mass spectrometric analysis of the solution containing $A \beta(1-40)$ which was prepared for immobilization on the sensor chip. The mass spectrum indicated that the amyloid beta peptide did not form aggregates. The authors verified also by MALDI-TOF mass spectrometry whether the decapeptide 
yields oligomers when incubated at a concentration of $20 \mu \mathrm{M}$ in $10 \mathrm{mM}$ PBS (pH 7.4) during $24 \mathrm{~h}$ and concluded that the peptide does not form aggregates [55].

RYYAAFFARR decapeptide inhibitor (RR) has proven to be an efficient protector of PC-12 cells (highly differentiated rat pheochromocytoma) against $\mathrm{A} \beta(1-40)$-induced toxicity, but to different extents. Cell viability after $A \beta(1-40)(20 \mu \mathrm{M})$ treatment was approximately $65 \%$ that of the control, whereas incubation of $A \beta 1-40$ with RR enhanced cell viability. Furthermore, RR in a molar ratio of 1:1 $(\mathrm{A} \beta(1-40) / \mathrm{RR})$ was sufficient to significantly prevent $\mathrm{A} \beta(1-40)$-induced toxicity and $\mathrm{A} \beta(1-40)$ aggregation. The viability of PC-12 cells increased to about $95 \%$ when $A \beta(1-40)$ was incubated with RR in a molar ratio of 1:4 (A $\beta(1-40) / R R)$, which was almost equal to the control. Because $A \beta$ neurotoxicity is related to the formation of the $\beta$-sheet structure, the MTT assay results suggest that $R R$ is an effective inhibitor of $A \beta(1-40)$ [55].

The bifunctional $A \beta$ aggregation inhibitor GGHRYYAAFFARR (GR), in which RYYAAFFARR (RR) acted as an aggregation inhibitor and GGH had chelator function for $\mathrm{Cu}(\mathrm{II})$ ions, was investigated in regards to cytotoxicity over neuronal PC12 cells (highly differentiated rat pheochromocytoma) by MTT assay. The addition of A $\beta$ fibrils-Cu complex and different transformation solutions with the same concentration of $A \beta$ to the cells, showed at $48 \mathrm{~h}$ an enhanced toxicity for $\mathrm{fA} \beta-\mathrm{Cu}$ (cell viabilities of $38 \%$ ), due presumably to the toxicity of $\beta$-sheet structure content and ROS generated by $\mathrm{Cu}$ in the presence of ascorbate [56]. The addition of GGH or RR has increased the cell survival rate by up to $46 \%$ and $48 \%$, respectively, being to only suppress the toxicity of just one aspect: GGH has merely reduced the ROS toxicity induced by $\mathrm{Cu}$, whereas RR has only decreased the $\beta$-sheet structure within aggregates. Thus, the cell viability has not been largely improved. The cell viability in the group treated with GR has greatly increased up to $70 \%$, through the combined effects of the chelator GGH $(46 \%)$ and single functional peptide RR (48\%). This is a strong evidence of the excellent potential of GR toward $\mathrm{Cu}$ ions chelation and $\mathrm{A} \beta$ degradation [56].

Another study investigated the capacity of GR on inhibiting the cytotoxicity of $\mathrm{A} \beta-\mathrm{Cu}(\mathrm{II})$ complex. The cell viability of the $A \beta$ group was $62 \%$ and the addition of $\mathrm{Cu}(\mathrm{II})$ ions greatly reduced cell viability to $35 \%$. When GGH was added, the cell viability could be significantly improved to $49 \%$ because of its ability to chelate $\mathrm{Cu}$ (II) ions and, in turn, inhibit $\mathrm{A} \beta$ aggregation. When GR, which has the ability to chelate $\mathrm{Cu}$ (II) ions and has anti-amyloid effect, was added, the cell viability improved to $88 \%$, significantly better than that of the RR group (68\%). This improvement illustrated the properties of the bifunctional inhibitor in reducing the cytotoxicity of $\mathrm{A} \beta-\mathrm{Cu}(\mathrm{II})$ complex and its advantage over the single functional inhibitors GGH and RR [57].

\subsection{RGTFEGKF Peptide}

Barucker and his collaborators analyzed the binding region from $A \beta(1-42)$ involved in the interaction with the peptide RGTFEGKF (named also AIP) using a UltrafleXtreme MALDI-TOF/TOF produced by Bruker Daltonics. The authors verified whether the peptides RGTFEGKF containing all L or all $\mathrm{D}$ amino acids are cleaved by trypsin and found that after $3 \mathrm{~h}$ incubation with trypsin there were no fragments in the mass spectra. They also proved that both octapeptides decreased the cleavage by trypsin of the peptide $A \beta(1-42)$ after the lysine- 28 by comparing the ratio between the area under curve obtained for each of the tryptic fragments $A \beta(1-16)$ and $A \beta(17-28)$ and for $A \beta(1-42)$ [58].

The investigation of AIP effects on neurotoxicity was assessed in SH-SY5Y cells. In the absence of AIP, freshly dissolved $A \beta(1-42)$ peptides (pre-incubated for 4 or $8 \mathrm{~h}$ ) reduced the number of living cells by approximately $40 \%$; under similar assay conditions, the presence of AIP was able to neutralize the $A \beta(1-42)$-induced neurotoxic effects. In the case of primary hippocampal neurons that were pre-incubated with $A \beta(1-42)$, AIP almost completely attenuated the $A \beta(1-42)$-mediated loss of living cells at $4 \mathrm{~h}^{\prime}$ time interval $[7,58]$. 


\section{Conclusions}

The verification by mass spectrometry of non-covalent complex formation between amyloid-beta peptides and the substances tested in vitro and in vivo for lowering the toxic effect of the amyloid-beta peptides is an important step for clarifying the mechanism of action for these substances (Figure 5).

Further studies should also use the recently developed method namely Intact Transition Epitope Mapping (ITEM) which allows a rapid analysis of an epitope recognized by an antibody and which could be applied to non-covalent complexes between low molecular weight molecules [59]. For additional information on the importance of each amino acid residue from the $A \beta$ region involved in complex formation with the substance analyzed peptides containing alanine single site mutations within $A \beta$ binding sequence could be produced by solid phase peptide synthesis and the complex formation could be investigated for each mutant peptide by mass spectrometry [60].

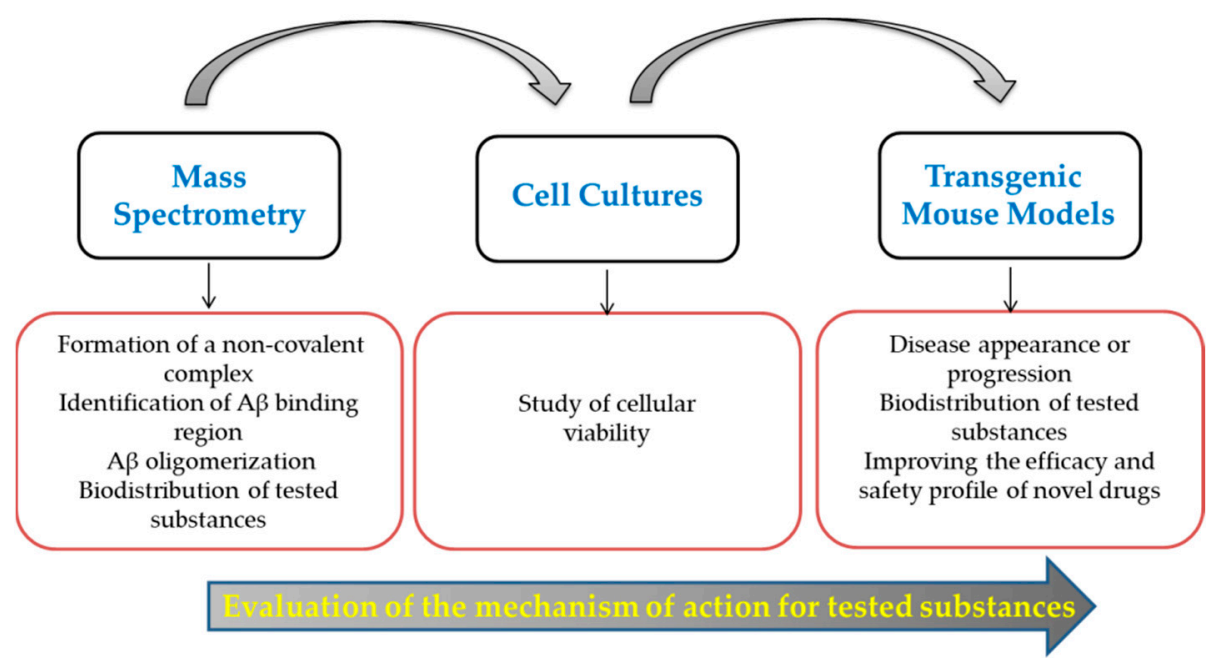

Figure 5. Workflow for the evaluation of the mechanism of action for potential inhibitors of A $\beta$ oligomerization.

Author Contributions: Conceptualization, R.S.; writing-original draft preparation, R.S., G.D.S., A.L., I.C.C., C.T.M.; supervision and critically reviewing the manuscript, B.I.T.; project administration, R.S.; funding acquisition, R.S. All the authors critically reviewed the manuscript. All the authors read and approved the final manuscript.

Funding: This research was funded by "Grigore T. Popa" University of Medicine and Pharmacy, from Iaşi, Romania, grant number 27498/20.12.2018.

Conflicts of Interest: The authors declare no conflict of interest. The funders had no role in the design of the study; in the collection, analyses, or interpretation of data; in the writing of the manuscript, or in the decision to publish the results.

\section{Abbreviations}

AD, Alzheimer's Disease; A $\beta$, Amyloid-beta; APP, Amyloid Precursor Protein; FAD, Familial Alzheimer's Disease; ABCA1 modulation, ATP binding cassette transporter A1; AD model with Npc1-deficient mice, a novel mouse model of "Juvenile Alzheimer's Disease" carrying a D1005G-Npc1 mutation; GluA1 and GluA2 subunits of $\alpha$-amino-3-hydroxy-5-methyl-4-isoxazolepropionic acid (AMPA) receptors; GluN2A, the main subunit of N-methyl-d-aspartate receptors; PSD-95, a membrane-associated guanylate kinase, is the major scaffolding protein in the excitatory postsynaptic density (PSD) and a potent regulator of synaptic strength; ESI, Electrospray ionization; MALDI, Matrix Assisted Laser Desorption and Ionization; iPSCs, Induced pluripotent stem cells; PS1, Presenilin 1; PS2, Presenilin 2; SH-SY5Y, Human neuroblastoma cell line; GAP-43, Growth-Associated Protein; NeuN, Neuronal Nuclei; SYN, Synaptophysin; SV2, Synaptic Vesicle Protein II; NSE, Neuron Specific Enolase; MAP, Microtubule Associated protein; GFAP, Glial Fibrillary Acidic Protein; SK-N-SH, Original Human Neuroblastoma Cell Line from which SH-SY5Y was derived; TH, Tyrosine Hydroxylase; GSK3 beta, Glycogen synthase kinase 3 beta; HN, Humanin peptide; Acm, Acetamidomethyl; NHS-Activated Sepharose, N-hydroxysuccinimide-Activated Sepharose; MALDI-TOF, Matrix Assisted Laser Desorption and Ionization-Time Of Flight; nano-ESI-FTICR, Nano-Electrospray Ionization-Fourier Transform Ion Cyclotron Resonance; PC12, Rat phaeochromocytoma; Bcl-2, B-cell lumphoma 2, antiapoptotic protein; Bax, Bcl-2-like 
protein 4, proapoptotic protein, Bax gene; icv, intracerebroventricular; ip, intraperitoneal; APPswe/PS1dE9 mice, double transgenic mouse model carrying APP Swedish mutation and deletion of presenilin 1 in exon 9; APPswe, tauP310L, PS1M146V mice, triple transgenic mouse model carrying APP Swedish mutation, Tau mutation P310L and presenilin 1 mutation M146V; 3xTg-AD mice, triple transgenic mouse model of Alzheimer's disease; Q-TOF, Quadrupole-Time Of Flight; LC/MS, Liquid Cromatography/Mass Spectrometry; Glu-C, Endoprotease V8 from Staphylococcus aureus; N2a, mouse neuroblastoma cell line; Tg2576 mice, transgenic mice overexpressing APP695 carrying Swedish mutation K670N and M671L; TgCRND8 mice, transgenic mouse model of Alzheimer's Disease overexpressing APP695 and carrying Swedish mutation K670N and M671L and Indiana mutation V717F; HP- $\beta$-CD, 1-hydroxypropyl- $\beta$-cyclodextrin; Tg19959 mice, transgenic mouse model of Alzheimer's disease, which overexpress human APP with the Swedish and Indiana familial AD mutations; Fmoc, 9-Fluorenylmethyloxycarbonyl; MTT, 3-(4,5-dimethylthiazol-2-yl)-2,5-diphenyltetrazolium bromide; fA $\beta$-Cu, Amyloid- beta fibrils Cu complex; ROS, Reactive Oxygen Species.

\section{References}

1. World Alzheimer Report 2018; Alzheimer's Disease International: London, UK, 2018.

2. Selkoe, D.J. Alzheimer's Disease: Genes, Proteins, and Therapy. Physiol. Rev. 2001, 81, 741-766. [CrossRef] [PubMed]

3. Kuperstein, I.; Broersen, K.; Benilova, I.; Rozenski, J.; Jonckheere, W.; Debulpaep, M.; Vandersteen, A.; Segers-Nolten, I.; Van Der Werf, K.; Subramaniam, V.; et al. Neurotoxicity of Alzheimer's disease A $\beta$ peptides is induced by small changes in the $\mathrm{A} \beta 42$ to $\mathrm{A} \beta 40$ ratio. EMBO J. 2010, 29, 3408-3420. [CrossRef]

4. Scheuner, D.; Eckman, C.; Jensen, M.; Song, X.; Citron, M.; Suzuki, N.; Bird, T.D.; Hardy, J.; Hutton, M.; Kukull, W.; et al. Secreted amyloid $\beta$-protein similar to that in the senile plaques of Alzheimer's disease is increased in vivo by the presenilin 1 and 2 and APP mutations linked to familial Alzheimer's disease. Nat. Med. 1996, 2, 864-870. [CrossRef]

5. Tanzi, R.E. The genetics of Alzheimer disease. Cold Spring Harb. Perspect. Med. 2012, 2, a006296. [CrossRef] [PubMed]

6. $\quad$ Bernstein, S.L.; Dupuis, N.F.; Lazo, N.D.; Wyttenbach, T.; Condron, M.M.; Bitan, G.; Teplow, D.B.; Shea, J.E.; Ruotolo, B.T.; Robinson, C.V.; et al. Amyloid- $\beta$ protein oligomerization and the importance of tetramers and dodecamers in the aetiology of Alzheimer's disease. Nat. Chem. 2009, 1, 326-331. [CrossRef] [PubMed]

7. Ryan, P.; Patel, B.; Makwana, V.; Jadhav, H.R.; Kiefel, M.; Davey, A.; Reekie, T.A.; Rudrawar, S.; Kassiou, M. Peptides, Peptidomimetics, and Carbohydrate-Peptide Conjugates as Amyloidogenic Aggregation Inhibitors for Alzheimer's Disease. ACS Chem. Neurosci. 2018, 9, 1530-1551. [CrossRef]

8. Opuni, K.F.M.; Al-Majdoub, M.; Yefremova, Y.; El-Kased, R.F.; Koy, C.; Glocker, M.O. Mass spectrometric epitope mapping. Mass Spectrom. Rev. 2018, 37, 229-241. [CrossRef] [PubMed]

9. Shipley, M.M.; Mangold, C.A.; Szpara, M.L. Differentiation of the SH-SY5Y Human Neuroblastoma Cell Line. J. Vis. Exp. 2016, e53193. [CrossRef] [PubMed]

10. Kovalevich, J.; Langford, D. Considerations for the Use of SH-SY5Y Neuroblastoma Cells in Neurobiology BT-Neuronal Cell Culture: Methods and Protocols. In Neuronal Cell Culture; Amini, S., White, M.K., Eds.; Humana Press: Totowa, NJ, USA, 2013; Volume 1078, pp. 9-21.

11. Ross, R.A.; Spengler, B.A.; Biedler, J.L. Coordinate morphological and biochemical interconversion of human neuroblastoma cells. J. Natl. Cancer Inst. 1983, 71, 741-747. [PubMed]

12. Eves, E.M.; Tucker, M.S.; Roback, J.D.; Downen, M.; Rosner, M.R.; Wainer, B.H. Immortal rat hippocampal cell lines exhibit neuronal and glial lineages and neurotrophin gene expression. Proc. Natl. Acad. Sci. USA 1992, 89, 4373-4377. [CrossRef] [PubMed]

13. Ross, C.A.; Akimov, S.S. Human-induced pluripotent stem cells: Potential for neurodegenerative diseases. Hum. Mol. Genet. 2014, 23, R17-R26. [CrossRef]

14. Perlman, R.L. Mouse Models of Human Disease: An Evolutionary Perspective. Evol. Med. Public Heal. 2016, eow014. [CrossRef]

15. Elder, G.A.; Sosa, M.A.G.; Gasperi, R. De Transgenic Mouse Models of Alzheimer 's Disease. Mt. Sinai Sch. Med. 2010, 77, 69-81. [CrossRef] [PubMed]

16. Kitazawa, M.; Medeiros, R.; Laferla, F.M. Transgenic Mouse Models of Alzheimer Disease: Developing a Better Model as a Tool for Therapeutic Interventions. Curr. Pharm. Des. 2012, 18, 1131-1147. [CrossRef]

17. Gong, Z.; Tas, E.; Muzumdar, R. Humanin and age-related diseases: A new link? Front. Endocrinol. (Lausanne) 2014, 5, 210. [CrossRef] 
18. Maftei, M.; Tian, X.; Manea, M.; Exner, T.E.; Schwanzar, D.; von Arnim, C.A.F.; Przybylski, M. Interaction structure of the complex between neuroprotective factor humanin and Alzheimer's $\beta$-amyloid peptide revealed by affinity mass spectrometry and molecular modeling. J. Pept. Sci. 2012, 18, 373-382. [CrossRef]

19. Jin, H.; Liu, T.; Wang, W.-X.; Xu, J.-H.; Yang, P.-B.; Lu, H.-X.; Sun, Q.-R.; Hu, H.-T. Protective effects of [Gly14]-Humanin on $\beta$-amyloid-induced PC12 cell death by preventing mitochondrial dysfunction. Neurochem. Int. 2010, 56, 417-423. [CrossRef] [PubMed]

20. Yen, K.; Wan, J.; Mehta, H.H.; Miller, B.; Christensen, A.; Levine, M.E.; Salomon, M.P.; Brandhorst, S.; Xiao, J.; Kim, S.; et al. Humanin Prevents Age-Related Cognitive Decline in Mice and is Associated with Improved Cognitive Age in Humans. Sci. Rep. 2018, 8, 1-10. [CrossRef] [PubMed]

21. Tajima, H.; Kawasumi, M.; Chiba, T.; Yamada, M.; Yamashita, K.; Nawa, M.; Kita, Y.; Kouyama, K.; Aiso, S.; Matsuoka, M.; et al. A humanin derivative, S14G-HN, prevents amyloid- $\beta$-induced memory impairment in mice. J. Neurosci. Res. 2005, 79, 714-723. [CrossRef]

22. Zhang, W.; Zhang, W.; Li, Z.; Hao, J.; Zhang, Z.; Liu, L.; Mao, N.; Miao, J.; Zhang, L. S14G-Humanin improves cognitive deficits and reduces amyloid pathology in the middle-aged APPswe/PS1dE9 mice. Pharmacol. Biochem. Behav. 2012, 100, 361-369. [CrossRef] [PubMed]

23. Niikura, T.; Sidahmed, E.; Hirata-Fukae, C.; Aisen, P.S.; Matsuoka, Y. A humanin derivative reduces amyloid beta accumulation and ameliorates memory deficit in triple transgenic mice. PLoS ONE 2011, 6, e16259. [CrossRef] [PubMed]

24. Park, T.Y.; Kim, S.H.; Shin, Y.C.; Lee, N.H.; Lee, R.K.C.; Shim, J.H.; Glimcher, L.H.; Mook-Jung, I.; Cheong, E.; Kim, W.K.; et al. Amelioration of neurodegenerative diseases by cell death-induced cytoplasmic delivery of humanin. J. Control. Release 2013, 166, 307-315. [CrossRef]

25. Martineau, E.; de Guzman, J.M.; Rodionova, L.; Kong, X.; Mayer, P.M.; Aman, A.M. Investigation of the noncovalent interactions between anti-amyloid agents and amyloid $\beta$ peptides by ESI-MS. J. Am. Soc. Mass Spectrom. 2010, 21, 1506-1514. [CrossRef]

26. Gervais, F.; Paquette, J.; Morissette, C.; Krzywkowski, P.; Yu, M.; Azzi, M.; Lacombe, D.; Kong, X.; Aman, A.; Laurin, J.; et al. Targeting soluble A $\beta$ peptide with Tramiprosate for the treatment of brain amyloidosis. Neurobiol. Aging 2007, 28, 537-547. [CrossRef] [PubMed]

27. Kocis, P.; Tolar, M.; Yu, J.; Sinko, W.; Ray, S.; Blennow, K.; Fillit, H.; Hey, J.A. Elucidating the A $\beta 42$ Anti-Aggregation Mechanism of Action of Tramiprosate in Alzheimer's Disease: Integrating Molecular Analytical Methods, Pharmacokinetic and Clinical Data. CNS Drugs 2017, 31, 495-509. [CrossRef] [PubMed]

28. Bazoti, F.M.; Tsarbopoulos, A.; Markides, K.E.; Bergquist, J. Study of the non-covalent interaction between amyloid- $\beta$-peptide and melatonin using electrospray ionization mass spectrometry. J. Mass Spectrom. 2005, 40, 182-192. [CrossRef]

29. Pappolla, M.A.; Sos, M.; Omar, R.A.; Bick, R.J.; Hickson-Bick, D.L.; Reiter, R.J.; Efthimiopoulos, S.; Robakis, N.K. Melatonin prevents death of neuroblastoma cells exposed to the Alzheimer amyloid peptide. J. Neurosci. Off. J. Soc. Neurosci. 1997, 17, 1683-1690. [CrossRef]

30. Matsubara, E.; Bryant-Thomas, T.; Quinto, J.P.; Henry, T.L.; Poeggeler, B.; Herbert, D.; Cruz-Sanchez, F.; Chyan, Y.J.; Smith, M.A.; Perry, G.; et al. Melatonin increases survival and inhibits oxidative and amyloid pathology in a transgenic model of Alzheimer's disease. J. Neurochem. 2003, 85, 1101-1108. [CrossRef] [PubMed]

31. Quinn, J.; Kulhanek, D.; Nowlin, J.; Jones, R.; Praticò, D.; Rokach, J.; Stackman, R. Chronic melatonin therapy fails to alter amyloid burden or oxidative damage in old Tg2576 mice: Implications for clinical trials. Brain Res. 2005, 1037, 209-213. [CrossRef]

32. Gong, Y.H.; Hua, N.; Zang, X.; Huang, T.; He, L. Melatonin ameliorates A $\beta 1-42$-induced Alzheimer's cognitive deficits in mouse model. J. Pharm. Pharmacol. 2018, 70, 70-80. [CrossRef]

33. Matsubara, E.; Vidal, R.; Pacheco-Quinto, J.; Pappolla, M.A.; Matsubara, E.; Vidal, R.; Pacheco-Quinto, J.; Poeggeler, B.; Zagorski, M.; Sambamurti, K. Melatonin Treatment Enhances A $\beta$ Lymphatic Clearance in a Transgenic Mouse Model of Amyloidosis Send Orders for Reprints to reprints@benthamscience.ae Melatonin Treatment Enhances A $\beta$ Lymphatic Clearance in a Transgenic Mouse Model of Amyloidosis. Curr. Alzheimer Res. 2018, 15, 1-6.

34. Bazoti, F.N.; Bergquist, J.; Markides, K.E.; Tsarbopoulos, A. Noncovalent interaction between amyloid-beta-peptide (1-40) and oleuropein studied by electrospray ionization mass spectrometry. J. Am. Soc. Mass Spectrom. 2006, 17, 568-575. [CrossRef] 
35. Bazoti, F.N.; Bergquist, J.; Markides, K.; Tsarbopoulos, A. Localization of the noncovalent binding site between amyloid-beta-peptide and oleuropein using electrospray ionization FT-ICR mass spectrometry. J. Am. Soc. Mass Spectrom. 2008, 19, 1078-1085. [CrossRef]

36. Omar, S.H.; Scott, C.J.; Hamlin, A.S.; Obied, H.K. Olive biophenols reduces alzheimer's pathology in SH-SY5Y cells and APPswe mice. Int. J. Mol. Sci. 2019, 20. [CrossRef]

37. Grossi, C.; Rigacci, S.; Ambrosini, S.; Ed Dami, T.; Luccarini, I.; Traini, C.; Failli, P.; Berti, A.; Casamenti, F.; Stefani, M. The Polyphenol Oleuropein Aglycone Protects TgCRND8 Mice against Aß Plaque Pathology. PLOS ONE 2013, 8, e71702. [CrossRef]

38. Pantano, D.; Luccarini, I.; Nardiello, P.; Servili, M.; Stefani, M.; Casamenti, F. Oleuropein aglycone and polyphenols from olive mill waste water ameliorate cognitive deficits and neuropathology. Br. J. Clin. Pharmacol. 2017, 83, 54-62. [CrossRef] [PubMed]

39. Xu, F.; Li, Y.; Zheng, M.; Xi, X.; Zhang, X.; Han, C. Structure Properties, Acquisition Protocols, and Biological Activities of Oleuropein Aglycone. Front. Chem. 2018, 6, 239. [CrossRef]

40. Qi, W.; Zhang, A.; Good, T.A.; Fernandez, E.J. Two disaccharides and trimethylamine N-oxide affect A $\beta$ aggregation differently, but all attenuate oligomer-induced membrane permeability. Biochemistry 2009, 48, 8908-8919. [CrossRef] [PubMed]

41. Liu, R.; Barkhordarian, H.; Emadi, S.; Park, C.B.; Sierks, M.R. Trehalose differentially inhibits aggregation and neurotoxicity of beta-amyloid 40 and 42. Neurobiol. Dis. 2005, 20, 74-81. [CrossRef]

42. Portbury, S.D.; Hare, D.J.; Sgambelloni, C.; Perronnes, K.; Portbury, A.J.; Finkelstein, D.I.; Adlard, P.A. Trehalose Improves Cognition in the Transgenic Tg2576 Mouse Model of Alzheimer's Disease. J. Alzheimer's Dis. 2017, 60, 549-560. [CrossRef] [PubMed]

43. Du, J.; Liang, Y.; Xu, F.; Sun, B.; Wang, Z. Trehalose rescues Alzheimer's disease phenotypes in APP/PS1 transgenic mice. J. Pharm. Pharmacol. 2013, 65, 1753-1756. [CrossRef] [PubMed]

44. Van Bulck, M.; Sierra-Magro, A.; Alarcon-Gil, J.; Perez-Castillo, A.; Morales-Garcia, J. Novel Approaches for the Treatment of Alzheimer's and Parkinson's Disease. Int. J. Mol. Sci. 2019, 20, 719. [CrossRef] [PubMed]

45. Camilleri, P.; Haskins, N.J.; Hewlett, D.R. $\beta$-Cyclodextrin interacts with the Alzheimer amyloid $\beta$-A4 peptide. FEBS Lett. 1994, 341, 256-258. [CrossRef]

46. Ren, B.; Jiang, B.; Hu, R.; Zhang, M.; Chen, H.; Ma, J.; Sun, Y.; Jia, L.; Zheng, J. HP- $\beta$-cyclodextrin as an inhibitor of amyloid- $\beta$ aggregation and toxicity. Phys. Chem. Chem. Phys. 2016, 18, 20476-20485. [CrossRef] [PubMed]

47. Yao, J.; Ho, D.; Calingasan, N.Y.; Pipalia, N.H.; Lin, M.T.; Beal, M.F. Neuroprotection by cyclodextrin in cell and mouse models of Alzheimer disease. J. Exp. Med. 2012, 209, 2501-2513. [CrossRef] [PubMed]

48. Maulik, M.; Westaway, D.; Jhamandas, J.H.; Kar, S. Role of cholesterol in APP metabolism and its significance in Alzheimer's disease pathogenesis. Mol. Neurobiol. 2013, 47, 37-63. [CrossRef] [PubMed]

49. Yang, D.S.; Stavrides, P.; Kumar, A.; Jiang, Y.; Mohan, P.S.; Ohno, M.; Dobrenis, K.; Davidson, C.D.; Saito, M.; Pawlik, M.; et al. Cyclodextrin has conflicting actions on autophagy flux in vivo in brains of normal and Alzheimer model mice. Hum. Mol. Genet. 2017, 26, 843-859. [CrossRef] [PubMed]

50. Cimini, S.; Sclip, A.; Mancini, S.; Colombo, L.; Messa, M.; Cagnotto, A.; Di Fede, G.; Tagliavini, F.; Salmona, M.; Borsello, T. The cell-permeable A $\beta 1-6$ A2VTAT(D) peptide reverts synaptopathy induced by A $\beta 1-42 w t$. Neurobiol. Dis. 2016, 89, 101-111. [CrossRef] [PubMed]

51. Di Fede, G.; Catania, M.; Maderna, E.; Morbin, M.; Moda, F.; Colombo, L.; Rossi, A.; Cagnotto, A.; Virgilio, T.; Palamara, L.; et al. Tackling amyloidogenesis in Alzheimer's disease with A2V variants of Amyloid- $\beta$. Sci. Rep. 2016, 6, 1-16. [CrossRef] [PubMed]

52. Giunta, B.; Hou, H.; Zhu, Y.; Rrapo, E.; Tian, J.; Takashi, M.; Commins, D.; Singer, E.; He, J.; Fernandez, F.; et al. HIV-1 tat contributes to Alzheimer's disease-like pathology in PSAPP mice. Int. J. Clin. Exp. Pathol. 2009, 2, 433-443.

53. Zheng, X.; Wu, C.; Liu, D.; Li, H.; Bitan, G.; Shea, J.E.; Bowers, M.T. Mechanism of C-Terminal Fragments of Amyloid $\beta$-Protein as $A \beta$ Inhibitors: Do C-Terminal Interactions Play a Key Role in Their Inhibitory Activity? J. Phys. Chem. B 2016, 120, 1615-1623. [CrossRef]

54. Li, H.; Du, Z.; Lopes, D.H.J.; Fradinger, E.A.; Wang, C.; Bitan, G. C-terminal tetrapeptides inhibit aß42-induced neurotoxicity primarily through specific interaction at the N-Terminus of A $\beta 42$. J. Med. Chem. 2011, 54, 8451-8460. [CrossRef] [PubMed] 
55. Liu, J.; Wang, W.; Zhang, Q.; Zhang, S.; Yuan, Z. Study on the efficiency and interaction mechanism of a decapeptide inhibitor of $\beta$-amyloid aggregation. Biomacromolecules 2014, 15, 931-939. [CrossRef] [PubMed]

56. Wang, D.; Zhang, Q.; Hu, X.; Wang, W.; Zhu, X.; Yuan, Z. Pharmacodynamics in Alzheimer's disease model rats of a bifunctional peptide with the potential to accelerate the degradation and reduce the toxicity of amyloid $\beta-\mathrm{Cu}$ fibrils. Acta Biomater. 2018, 65, 327-338. [CrossRef]

57. Zhang, Q.; Hu, X.; Wang, W.; Yuan, Z. Study of a Bifunctional A $\beta$ Aggregation Inhibitor with the Abilities of Antiamyloid- $\beta$ and Copper Chelation. Biomacromolecules 2016, 17, 661-668. [CrossRef] [PubMed]

58. Barucker, C.; Bittner, H.J.; Chang, P.K.Y.; Cameron, S.; Hancock, M.A.; Liebsch, F.; Hossain, S.; Harmeier, A.; Shaw, H.; Charron, F.M.; et al. A $\beta 42$-oligomer Interacting Peptide (AIP) neutralizes toxic amyloid- $\beta 42$ species and protects synaptic structure and function. Sci. Rep. 2015, 5, 15410. [CrossRef] [PubMed]

59. Yefremova, Y.; Opuni, K.F.M.; Danquah, B.D.; Thiesen, H.J.; Glocker, M.O. Intact Transition Epitope Mapping (ITEM). J. Am. Soc. Mass Spectrom. 2017, 28, 1612-1622. [CrossRef] [PubMed]

60. Ștefănescu, R.; Lupu, L.; Manea, M.; Iacob, R.E.; Przybylski, M. Molecular characterization of the $\beta$-amyloid(4-10) epitope of plaque specific $A \beta$ antibodies by affinity-mass spectrometry using alanine site mutation. J. Pept. Sci. 2018, 24, e3047. [CrossRef] [PubMed]

(C) 2019 by the authors. Licensee MDPI, Basel, Switzerland. This article is an open access article distributed under the terms and conditions of the Creative Commons Attribution (CC BY) license (http:/ / creativecommons.org/licenses/by/4.0/). 